\title{
Rhizoctonia solani AG4 異常株の発現と消失
}

\author{
百町 満朗*.角野 晶大**・本間 善久*** \\ Mitsuro Hyakumachi*, Akio Sumino** and Yoshihisa Homma***: \\ Occurrence or Disappearance of Abnormal Isolates \\ in Rhizoctonia solani AG4
}

\begin{abstract}
Occurrence or disappearance of abnormality in normal or abnormal isolates of Rhizoctonia solani anastomosis group 4 (AG4) by several treatments were examined. Abnormality has not disappeared by heat $(40 \sim 60 \mathrm{C})$ treatment, chemical (streptomycin sulfate, oxytetracycline, chloramphenicol, cycloheximide, ethidium bromide, acriflavine) treatment, hyphal tip or mass transfer, and single protoplast isolation of abnormal isolates. On the other hand, abnormal isolates occurred from healthy isolates by single protoplast isolation and hyphal tip transfer with low frequency of $0.9 \%$ and $0.2 \%$, respectively. These results showed that agent(s) stimulating abnormality had already existed in healthy isolates. Development of abnormality was also highly seen when normal isolates were dipped into a culture broth or macerated suspension of abnormal isolates. However, it was not seen in the case of a culture broth or macerated suspension filtrated through membrane $(0.45 \mu \mathrm{m})$. Lethal isolates which produced brownblack pigment in medium and could not survive after transfer were obtained both from normal and abnormal isolates. Besides agent(s) stimulating abnormality, the existence of lethal agent(s) has been suggested.
\end{abstract}

(Received August 1, 1988)

Key words: fungal abnormality, Rhizoctonia solani AG4, abnormal agent(s), lethal agent(s).

\section{緒言}

数種の植物病原糸状菌には, 培養形態が異常を呈 し, 生育が遅く, 病原性の弱い株が存在する。さら に, これら異常株の中には菌糸融合により正常な株を 異常にし, 病原性を低下させる株の存在が知られてい

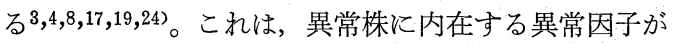
細胞質内を移行し正常株に入り込んだ結果, 正常株が 異常になったためと考兄られている。異常因子とし

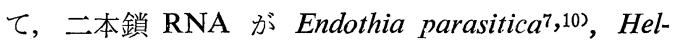
minthosporium victoriae ${ }^{23)}$ および Rhizoctonia solani ${ }^{6)}$ で, プラスミド DNA が R. solani ${ }^{14)}$ で, および d-
因子が Ceratocystis ulmi ${ }^{3)}$ で報告されている。これら の菌では異常因子が正常株に導入されると病原性が低 下することから，異常因子を利用した生物防除の可能 性が示唆されている1,5,11,13,20,26,27)。一方，植物病原 菌を含む数種の糸状菌では, 異常株の培養液や菌体破 砕液に正常株を浸漬することで, 正常株が異常株にな

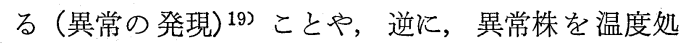
理 2 ,22,28) したり抗生物質や色素を処理 $9,10,25)$ すること により, あるいは, 異常株の菌系先端部を移植4,22) し たり，単プロトプラスト分離 ${ }^{12)}$ 常株が正常株に回復する（異常の消失）ことが知られ ている。

\footnotetext{
* 岐阜大学農学部 Faculty of Agriculture, Gifu University, 1-1 Yanagido, Gifu 501-11, Japan

** サントリー (株) 研究センター基礎研究所 Institute for Fundamental Research, Research Center, Suntory Ltd., 1-1-1 Wakaya-Dai, Shimamoto-Cho, Mishima-Gun, Osaka 618, Japan

*** 北海道農業試験場 Hokkaido National Agricultural Experiment Station, Toyohira-ku, Sapporo 004, Japan
} 
本研究は $R$. solani 菌系融合群第 4 群 [anastomosis group (AG)4] の正常株と異常株を用いて，各種処理 による異常の発現と消失の有無を調へ，異常の発現機 構解明への手掛りを得ることを目的とした。

\section{実験材料および方法}

供試菌株 R. solani AG4 の正常株 1271 と 1271L, 抢よび異常株 RI64 と RI66 を用いた。1271L は 1271 の継代培養中に出現した株で, 1271 に比べ菌叢 が蹯で，褐色色素による培地着色が著しいが，異常株 とは明らかに異なり，正常な生育を示す。異常株 RI64 と RI66 は正常株 1271 を土垬に繰り返し接種してダ イコン苗立枯病が衰退した土壌から分離された ${ }^{16)}$ 。

異常の発現と消失の判定 異常の発現と消失は, ジ ヤガイモ・グルコース・寒天培地 (PDA) 上での菌系 生育速度と菌叢形態で判定した。すなわち, 各処理後 の菌体を PDA 斜面培地飞移植し，25 C, 3 週間培養 中の菌系の伸びと菌叢の形態を調へ，正常株と同様の ものは正常株，異常株と同様なものは異常株とした。

\section{異常株の培養液および菌体破砕液への浸漬処理}

異常株を $15 \mathrm{ml}$ の $2 \%$ 蔗糖加用ジャガイモ煎汁液体 培地 (PSB) で $25 \mathrm{C}, 2$ 週間静置培養後, 濾紙（東洋 濾紙 No. 1) で濾過したものを「培垷液の原液」とし， また，菌体と培養液を $1: 2(\mathrm{w} / \mathrm{v})$ の割合で混合し， ワ ーリングブレンダーで 10,000 rpm，5分間破砕したも のを「破砕液の原液」とした。実験にはこれらの原液 のほか，培養液の原液を殺菌蒸留水で， $1 / 1,1 / 10$, $1 / 100$ に希勫した液，打よび孔径 $0.45 \mu \mathrm{m}$ のメンブラ ンフィルターで除菌した液, また, 破碎液の原液をメ ンブランフィルターで除菌した液，拉よび破砕液の原 液をフェノールで除たんぱく処理した液を用いた。こ れらの各液に, PDA 上で, $25 \mathrm{C}, 1$ 週間培養した正 常株の菌叢から, 直径 $5 \mathrm{~mm}$ のコルクボーラーで打

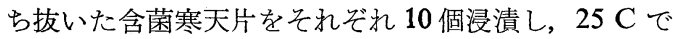
48 時間培盖した。培養後, 含菌寒天片を取り出し, 隇 菌滤紙で水分を取り除き,酸性素寒天平板培地 (AWA, $\mathrm{pH}$ 4.5) に移植した。2 3 日後, AWA 上に伸展した 菌系の先端部 $\left(4 \mathrm{~mm}^{2}\right)$ をPDA 斜面培地に移植し，菌 糸伸長と培養形態を調べた。な誩，対照として PSB 48 時間浸漬培養した正常株の含菌寒天片を PDA 斜面 培地に移植し，菌糸伸長と培養形態を調べた。実験は 4 反復行った。

温度処理 PDA 斜面培地で $25 \mathrm{C}, 1$ 週間培養した 正常株 1271 と異常株 RI64を，それぞれ試験管ごと $40 \mathrm{C} ， 45 \mathrm{C} ， 50 \mathrm{C} ， 55 \mathrm{C}$ 抢よび $60 \mathrm{C}$ に調整したウ
オーターバス内に 10 分, 20 分抢よび 30 分間浸漬し た。浸漬後, 菌系片 $(5 \mathrm{~mm} \times 5 \mathrm{~mm})$ を切り取り, 新 たに PDA 斜面培地に移植し, 菌系伸長と培養形態を 調べた。実験は各区につき 10 個の菌糸片を供試し， それぞれ 3 反復行った。

抗生物質処理 および色素処理 ストレプトマイシ ン・サルフェイト, オキシテトラサイクリン, クロラ ムフェニコール，シクロヘキシミドの各抗生物質と臭 化エチジウム, アクリフラビンの各色素を所定濃度 (Table 3) 加えたPDA 平板培地に異常株 RI64 と RI66 を移植し， $25 \mathrm{C} ， 3$ 日間培養した。培養後 PDA 上飞 生育した菌叢先端部の菌系片 $(5 \mathrm{~mm} \times 5 \mathrm{~mm})$ をPDA 斜面培地に移植し，菌采伸長と培養形態を調べた。対 照として正常株 1271 抢よび異常株 RI64 と RI66を 抗生物質や色素を含まないPDA 上に移植し，菌系伸 長と培養形態を調べた。なお，実験はそれぞれ 5 個の 菌系片を用い 2 反復行った。

菌糸先端部移植および菌糸片移植 菌系先端部移植 は正常株と異常株をそれぞれ素寒天培地 (WA) 飞 $25 \mathrm{C} ， 2 \sim 3$ 日間培養後, 伸展した 1 本の主軸菌系の 先端部約 $2 \mathrm{~mm}^{2}$ 150 個切り取り, PDA 斜面培地 に移植し，菌系伸長と培養形態を調べた。比較として WA 平板上に生育した菌叢先端部の菌糸片 $(5 \mathrm{~mm} \times$ $5 \mathrm{~mm}$ )を同様に移植した。

単プロトプラスト分離 正常株と異常株からのプロ トプラストの作成拉よび再生は Hashiba and Yamada ${ }^{15)}$ の方法に準じた。すなわち，1\% ペプトン加用 PSB で $25 \mathrm{C}, 15 \sim 20$ 時間培養した菌体 $1 \mathrm{~g}$ を $\beta$ グ ルクロニターゼ $0.06 \mathrm{ml} / \mathrm{ml}$ ，セルラーゼオノッ゙カ R-S $20 \mathrm{mg} / \mathrm{ml}$ ，マセロチーム R-10 $5 \mathrm{mg} / \mathrm{ml}$ を含を $0.6 \mathrm{M}$ マニトール液 $(\mathrm{pH} 5.2) 10 \mathrm{ml}$ に懸濁後, $30 \mathrm{C}$ で緩く 3 時間振盪培養した。培養後, 二重ガーゼで滤過し, 濾液を $2,500 \mathrm{rpm}, 5$ 分間遠心分離し，粗プロトプラ ストを集めた。0.6 M マニトール液で数度洗浄した粗 プロトプラストを $2 \mathrm{ml}$ の $0.6 \mathrm{M}$ マニトール液に懸濁 後, $0.6 \mathrm{M}$ 蔗楉液 $4 \mathrm{ml}$ の上に静かに積層し，1,000 $\mathrm{rpm} ， 5$ 分間遠心分離した。二層の界面に集まったプ ロトプラストをパストゥールピペットで取り出し，こ れを単プロトプラスト分離に供試した。各菌株のプロ トプラスト懸濁液をそれぞれ $0.6 \mathrm{M}$ マニトール加用 WA 上に流し, $25 \mathrm{C}$ で培養した。2 4 時間後, 発芽した プロトプラストを単胞子分離の要領でそれぞれ 150 206 個分離し, PDA 斜面培地飞移植し，菌系伸長々 培養形態を調べた。 


\section{結果}

\section{異常株の培養液および菌体破砕液への浸漬処理によ}

\section{る異常の発現}

正常株 1271 と $1271 \mathrm{~L}$ を異常株の培養液の原液に 浸漬すると，異常株と暗褐色の色素を産生して死隇す る致死株が多数出現した（Table 1)。また，培養液を $1 / 10$ と $1 / 100$ 亿希釈して子異常株や致死株が出現し たが，その出現頻度は希釈が増すにつれて減少した。 一方，メンブランフィルターで除菌した培養液に浸漬 すると異常株は出現せず，致死株の及が出現した。致 死株の出現は 1271 より 1271L で多かった。

正常株 1271 と $1271 \mathrm{~L}$ を異常株の菌体破砕液に浸 漬すると，高頻度で異常株や致死株が出現した(Table 2)。培養液と同様に菌体破砕液をメンブランフィルタ 一で除菌すると，異常株は出現せず致死株の久が出現 した。一方，菌体破砕液をつェノール処理すると，異 常株や致死株は出現しなかった。

\section{温度処理による異常の発現と消失}

いずれの処理区とも正常株からは正常株，異常株か
らは異常株のみが出現し,温度処理による異常の発現, 消失は認められなかった。

\section{抗生物質処理および色素処理による異常の消失}

抗生物質や色素を添加したPDA上での異常株 RI64 と RI66 の菌糸伸長速度は無添加の場合と大差はなか ったが，対照とした正常株 1271 の伸長速度と比較す ると明らかに劣った( Fable 3)。また, 抗生物質や色素 を含む培地上で生育した異常株の菌叢から菌系片を取 り出し, 新たに PDA 斜面培地に移植しても, 菌系の 生育は悪く，培養形態は異常を呈したままであった。 すなわち, 異常株飞抗生物質や色素を処理しても異常 の消失は認められなかった。

\section{菌糸先端移植および菌糸片移植による異常の発現と} 消失

正常株 1271 の菌系先端部を移植した 242 株からは 異常株は出現しなかったが，1271L から移植した 302 株のうち 1 株（1271LHTD1）(0.3\%) は異常を呈し, 正常株からの異常の発現が認められた（Table 4) (Plate I-1)。一方, 異常株 RI64 と RI66 の菌系先端 部を移植した合計 543 株からは正常株は出現しなかっ

Table 1. Occurrence of abnormality in normal isolates of Rhizoctonia solani AG4 by dipping into culture broth of abnormal isolate treated in various ways

\begin{tabular}{|c|c|c|c|c|c|}
\hline \multirow{2}{*}{$\begin{array}{l}\text { Normal } \\
\text { isolate }\end{array}$} & \multirow{2}{*}{$\begin{array}{l}\text { Culture } \\
\text { broth }^{\text {a) }}\end{array}$} & \multirow[b]{2}{*}{ Treatment $b$ ) } & \multicolumn{3}{|c|}{ Appearance $(\%)^{d)}$ of } \\
\hline & & & $\begin{array}{l}\text { Normal } \\
\text { isolate }\end{array}$ & $\begin{array}{c}\text { Abnormal } \\
\text { isolate }\end{array}$ & $\begin{array}{l}\text { Lethal } \\
\text { isolate }\end{array}$ \\
\hline \multirow[t]{9}{*}{1271} & A & $1 / 1$ & 15 & 85 & 0 \\
\hline & & $1 / 10$ & 90 & 10 & 0 \\
\hline & & $1 / 100$ & 100 & 0 & 0 \\
\hline & & $1 / 1, \quad M$ & 55 & 0 & 45 \\
\hline & B & $1 / 1$ & 25 & 35 & 40 \\
\hline & & $1 / 10$ & 100 & 0 & 0 \\
\hline & & $1 / 100$ & 100 & 0 & 0 \\
\hline & & $1 / 1, \quad M$ & 55 & 0 & 45 \\
\hline & Control $^{c}$ ) & & 100 & 0 & 0 \\
\hline \multirow[t]{9}{*}{$1271 \mathrm{~L}$} & A & $1 / 1$ & 0 & 50 & 50 . \\
\hline & & $1 / 10$ & 65 & 15 & 20 \\
\hline & & $1 / 100$ & 55 & 20 & 25 \\
\hline & & $1 / 1, \quad M$ & 23 & 0 & 78 \\
\hline & B & $1 / 1$ & 40 & 50 & 10 \\
\hline & & $1 / 10$ & 25 & 55 & 20 \\
\hline & & $1 / 100$ & 85 & 5 & 10 \\
\hline & & $1 / 1, M$ & 45 & 0 & 55 \\
\hline & Control & & 100 & 0 & 0 \\
\hline
\end{tabular}

a) A: obtained from the abnormal isolate RI64.

$\mathrm{B}$ : obtained from the abnormal isolate RI66.

b) Diluted $1 / 1,1 / 10$ and $1 / 100$ with sterile distilled water.

$\mathrm{M}$ : filtrate passed through the membrane $(0.45 \mu \mathrm{m})$.

c) Dipped into PSB ( $2 \%$ potato sucrose broth).

d) Out of total 40 mycelial fragments. 
Table 2. Occurrence of abnormality in normal isolates of Rhizoctonia solani AG4 by dipping into macerated suspension of abnormal isolates treated in various ways

\begin{tabular}{|c|c|c|c|c|c|}
\hline \multirow{2}{*}{$\begin{array}{l}\text { Normal } \\
\text { isolate }\end{array}$} & \multirow{2}{*}{$\begin{array}{l}\text { Macerated a) } \\
\text { suspension }\end{array}$} & \multirow[b]{2}{*}{ Treatment $b$ ) } & \multicolumn{3}{|c|}{ Appearance $(\%)^{d)}$ of } \\
\hline & & & $\begin{array}{l}\text { Normal } \\
\text { isolate }\end{array}$ & $\begin{array}{c}\text { Abnormal } \\
\text { isolate }\end{array}$ & $\begin{array}{l}\text { Lethal } \\
\text { isolate }\end{array}$ \\
\hline \multirow[t]{7}{*}{1271} & A & M & 33 & 55 & 13 \\
\hline & & MM & 46 & 0 & 55 \\
\hline & & PM & 100 & 0 & 0 \\
\hline & B & $\mathbf{M}$ & 28 & 0 & 73 \\
\hline & & MM & 68 & 0 & 33 \\
\hline & & PM & 100 & 0 & 0 \\
\hline & Control $^{\mathrm{c}}$ ) & & 100 & 0 & 0 \\
\hline \multirow[t]{7}{*}{$1271 \mathrm{~L}$} & A & M & 10 & 83 & 8 \\
\hline & & MM & 38 & 0 & 63 \\
\hline & & PM & 100 & 0 & 0 \\
\hline & B & M & 40 & 13 & 48 \\
\hline & & MM & 33 & 0 & 68 \\
\hline & & PM & 100 & 5 & 0 \\
\hline & Control & & 100 & 0 & 0 \\
\hline
\end{tabular}

a) A: obtained from the abnormal isolate RI64.

B: obtained from the abnormal isolate RI66.

b) $\mathrm{M}$ : macerated suspension of mycelium.

MM: macerated suspension of mycelium filtered through the membrane $(0.45 \mu \mathrm{m})$.

PM: phenol extract of macerated suspension of mycelium.

c) Dipped into PSB $(2 \%$ potato sucrose broth).

d) Out of total 40 mycelial fragments.

Table 3. Effect of various antibiotics and dyes on mycelial growth of the abnormal isolates of Rhizoctonia solani AG4

\begin{tabular}{lrcc}
\hline & & \multicolumn{2}{c}{$\begin{array}{c}\text { Growth length of mycelium } \\
\text { on PDA during } 3 \text { days (mm) }\end{array}$} \\
\cline { 2 - 4 } Antibiotic or dye & Concentration & RI64 & RI66 \\
\hline Streptomycin sulfate & $10 \mu \mathrm{g} / \mathrm{ml}$ & 49 \\
& $100 \mu \mathrm{g} / \mathrm{ml}$ & 44 & 8 \\
Oxytetracycline & $1,000 \mu \mathrm{g} / \mathrm{ml}$ & 46 & 22 \\
& $10 \mu \mathrm{M} / \mathrm{ml}$ & 39 & 21 \\
Chloramphenicol & $100 \mu \mathrm{M} / \mathrm{ml}$ & 35 & 7 \\
& $1,000 \mu \mathrm{M} / \mathrm{ml}$ & 26 & 13 \\
Cycloheximide & $10 \mu \mathrm{M} / \mathrm{ml}$ & 42 & 21 \\
& $100 \mu \mathrm{M} / \mathrm{ml}$ & 43 & 13 \\
Ethidium bromide & $1,000 \mu \mathrm{M} / \mathrm{ml}$ & 9 & 23 \\
& $5 \mu \mathrm{M} / \mathrm{ml}$ & 14 & 5 \\
Acriflavine & $10 \mu \mathrm{M} / \mathrm{ml}$ & 10 & 3 \\
& $50 \mu \mathrm{M} / \mathrm{ml}$ & 1 & 7 \\
No treatment & $10 \mu \mathrm{M} / \mathrm{ml}$ & 38 & 14 \\
Control a) & $100 \mu \mathrm{M} / \mathrm{ml}$ & 5 & 13 \\
& $500 \mu \mathrm{M} / \mathrm{ml}$ & 4 & 1 \\
\hline
\end{tabular}

a) Normal isolate 1271 . 
Table 4. Occurrence or disappearance of abnormality in Rhizoctonia solani AG4 caused by hyphal mass or tip transfers

\begin{tabular}{|c|c|c|c|c|}
\hline \multirow[b]{2}{*}{ Transfer } & \multirow[b]{2}{*}{ Isolate $^{\text {a) }}$} & \multicolumn{3}{|c|}{ Appearance of } \\
\hline & & $\begin{array}{l}\text { Normal } \\
\text { isolate }\end{array}$ & $\begin{array}{c}\text { Abnormal } \\
\text { isolate }\end{array}$ & $\begin{array}{l}\text { Lethal } \\
\text { isolate }\end{array}$ \\
\hline \multirow[t]{8}{*}{ Hyphal mass } & 1271 & $150 / 150 \mathrm{~b})$ & $0 / 150$ & $0 / 150$ \\
\hline & & $100.0 \%$ & $0.0 \%$ & $0.0 \%$ \\
\hline & $1271 \mathrm{~L}$ & $110 / 150$ & $0 / 150$ & $40 / 150$ \\
\hline & & $73.3 \%$ & $0.0 \%$ & $26.6 \%$ \\
\hline & RI64 & $0 / 150$ & $149 / 150$ & $1 / 150$ \\
\hline & & $0.0 \%$ & $99.3 \%$ & $0.7 \%$ \\
\hline & RI66 & $0 / 150$ & $47 / 150$ & $103 / 150$ \\
\hline & & $0.0 \%$ & $31.3 \%$ & $68.7 \%$ \\
\hline \multirow[t]{8}{*}{ Hyphal tip } & 1271 & $242 / 242$ & $0 / 242$ & $0 / 242$ \\
\hline & & $100.0 \%$ & $0.0 \%$ & $0.0 \%$ \\
\hline & $1271 \mathrm{~L}$ & $149 / 302$ & $1 / 302$ & $152 / 302$ \\
\hline & & $49.3 \%$ & $0.3 \%$ & $50.3 \%$ \\
\hline & RI64 & $0 / 245$ & $245 / 245$ & $0 / 245$ \\
\hline & & $0.0 \%$ & $100.0 \%$ & $0.0 \%$ \\
\hline & RI66 & $0 / 298$ & $76 / 298$ & $222 / 298$ \\
\hline & & $0.0 \%$ & $25.5 \%$ & $74.5 \%$ \\
\hline
\end{tabular}

a) 1271 and $1271 \mathrm{~L}$ : normal isolates.

RI64 and RI66: abnormal isolates.

b) No. of normal, abnormal or lethal isolates / No. of isolates tested.

Table 5. Occurrence or disappearance of abnormality in Rhizoctonia solani AG4 caused by single protoplast isolation

\begin{tabular}{lcccc}
\hline \multirow{2}{*}{ Isolate } & & \multicolumn{3}{c}{ Appearance of } \\
\cline { 3 - 5 } & & $\begin{array}{c}\text { Normal } \\
\text { isolate }\end{array}$ & $\begin{array}{c}\text { Abnormal } \\
\text { isolate }\end{array}$ & $\begin{array}{c}\text { Lethal } \\
\text { isolate }\end{array}$ \\
\hline Normal & 1271 & $132 / 150^{\text {a }}$ & $3 / 150$ & $15 / 150$ \\
& & $88.0 \%$ & $2.0 \%$ & $10.0 \%$ \\
& $1271 \mathrm{~L}$ & $163 / 194$ & $0 / 194$ & $31 / 194$ \\
Abnormal & & $84.0 \%$ & $0.0 \%$ & $16.0 \%$ \\
& RI64 & $0 / 195$ & $195 / 195$ & $0 / 195$ \\
& & $0.0 \%$ & $100.0 \%$ & $0.0 \%$ \\
& RI66 & $0 / 206$ & $46 / 206$ & $160 / 206$ \\
& & $0.0 \%$ & $22.3 \%$ & $77.7 \%$ \\
\hline
\end{tabular}

a) No. of normal, abnormal or lethal isolates / No. of isolates tested.

た。菌叢先端部の菌糸片を移植した場合は，正常株か ら異常株あるいは異常株から正常株が出現することは なかった。正常株 1271L や異常株 RI66 では菌糸先 端部あるいは菌糸片を移植することにより致死株が高 頻度に出現した。

\section{単プロトプラスト分離による異常の発現と消失}

正常株 1271 の単プロトプラスト分離株 150 株のう ち 3 株 (1271PD1, 1271PD2, 1271PD3) (0.2\%) が 異常を呈し，正常株からの異常の発現が認められた
(Table 5) (Plate I-2)。正常株 1271L の単プロトプラ スト分離株 194 株からは異常株は出現しなかった。ま た，異常株 RI64 と RI66 の単プロトプラスト分離株 の合計 401 株からは正常株の出現は認められなかっ た。一方，正常株 1271 と 1271L 执よび異常株 RI66 を単プロトプラスト分離することにより，致死株はそ れぞれ $10.0 \% ， 16.0 \%$ および $77.7 \%$ の割合で出現 した。 


\section{考察}

今回の実験結果, Rhizoctonia solani AG4 の正常株 を異常株の培養液や菌体破砕液に浸漬することで異常 株が高率江出現すること，また，正常株の菌系先端部 を移植したり，単プロトプラスト分離しても低率なが ら異常株が出現することが明らかになった。異常株の 培養液やその希釈液拉よび菌体破砕液に正常株を浸漬 することにより，正常株から異常株が出現したことは， Lindberg ${ }^{19)}$ が Helminthosporium victoriae で行った実 験と同様の結果であり,これらの溶液中に異常因子が 存在したことを示唆している。一方，これらの液を入 ンブランフィルターで除菌すると異常の発現はみられ なかった。このことは，培養液や菌体破碎液に含まれ ていた異常株が移植後，正常株に混じって出現した可 能性を示している。しかし培養液は濾紙で大部分の菌 体が取り除かれていたにもかかわらず，異常株が高頻 度に出現したこと，あるい㥉養液を $1 / 100$ 亿希釈し てもな扮異常株が出現したことから, 異常の発現が単 に液体中に残存した異常株の菌体による混入とは考兄 難い。

本実験に供試した異常株は，正常株を土壤に繰り返 し接種し, 病気が衰退した土壤から分離された ${ }^{16}$ が， 正常株が異常株に変化した理由として，(1) 異常因子 を含む微生物の正常株への感染と，（2）正常株自体に 内在していた異常因子の增殖, の 2 点が考光られてい た。今回, 正常株の菌采先端部移植や単プロトプラス ト分離によりきわめて低頻度ながらも異常株が出現し たことは，正常株の菌体中にすでに異常因子が存在し ていたことを示するのであり，後者の説を裏付けてい る。また，このことは「正常株の継代培養中に生じた セクター部分か.ら異常株が出現した」との百町ら ${ }^{17) の ~}$ 結果とも一致する。

正常株を異常株の培養液や菌体破䂶液に浸漬する と，あるいは正常株と異常株を菌系先端部移植したり 単プロトプラスト分離すると, 高頻度に致死株が出現 した。致死株は, 培養液や菌体破砕液をメンブランフ ィルターで除菌しても出現したことから，異常因子と は異なる因子（致死因子）の存在が示唆された。また， メンブランフィルターで除菌後の菌体破碚液をフェ, 一ル処理すると，異常株や致死株の出現はまったく認 められなかった。このことは，H. victoriae の結果 ${ }^{21)}$ 之類似して招り，菌類ウイルスが異常因子や致死因子
として関与している可能性を示している。菌類の異常 因子が二本鎖 RNA（菌類ウイルス）の場合は，温度 処理 $2,22,28)$, 抗生物質処理 ${ }^{100}$, 菌系先端部移植 ${ }^{4)}$ 特よび 単プロトプラスト分離12)により，また，プラスミド DNA の場合には抗生物質処理や色素処理9,25) に上 り，異常株から正常株が出現するとの報告がある。こ れらの处理は異常因子を除去したり, あるいは異常因 子を不活化させると考兄られている。しかし，本実験 では上記のいずれの処理に执いても異常株から正常株 が出現することはなかった。この結果は，異常因子が 菌体内で一旦増殖すると，それを取り除いたり不活化 することがきわめて難しいことを示している。

植物病原系状菌の異常因子が何であるかを明確にす ることは，異常株あるいは異常因子を用いた生物防除 法を確立する上できわめて重要である。本実験で用い た異常株は, Castanho and Butler ${ }^{5)}$ が報告した $R$. solani AG1 の異常株々同様, 病原性が弱く, また, 正 常株に干渉作用を示す17) ととから，異常因子が病原性 飞密接に関与していると思われる。この異常株から は，これまでに二本鎖 RNA ${ }^{18)}$ とプラスミド DNA ${ }^{14)}$ が検出されている。これら核外遺伝子と異常との関係 を明らかにすることは今後の課題である。

\section{摘 要}

各種処理による Rhizoctonia solani 菌糸融合群第 4 群の正常株と異常株飞批ける異常の発現と消失を調べ た。異常株を温度 $(40 \mathrm{C} \sim 60 \mathrm{C}$ ) 処理, 薬剂（ストレ プトマイシン・サルフェイト，オキシテトラサイク リン, クロラムフェニコール, シクロヘキシミド, 臭 化エチジウム，アクリフラビン）処理, 菌系先端部移 植，菌糸片移植执よび単プロトプラスト分離したが， 異常株から正常株が出現することはなかった。一方, 正常株を単プロトプラスト分離すると, 分離した 344 株のらち 3 株 $(0.9 \%)$ が，また，菌系先端部移植する と, 移植した 544 菌株のらち 1 株 $(0.2 \%)$ が異常を呈 し，正常株から異常株の出現が認められた。このこと は，異常因子が正常株中にすでに存在していることを 示している。正常株を異常株の培養液と菌体破碟液に 浸漬すると異常株が高率に出現したが,これらの液を, 孔径 $0.45 \mu \mathrm{m}$ のメンブランフィルターで除菌すると異 常株は出現しなかった。暗褐色の色素を産生して死隇 する致死株が正常株と異常株の両者から出現したが, 異常因子とは異なる致死因子の存在が示唆された。 


\section{Plate I}
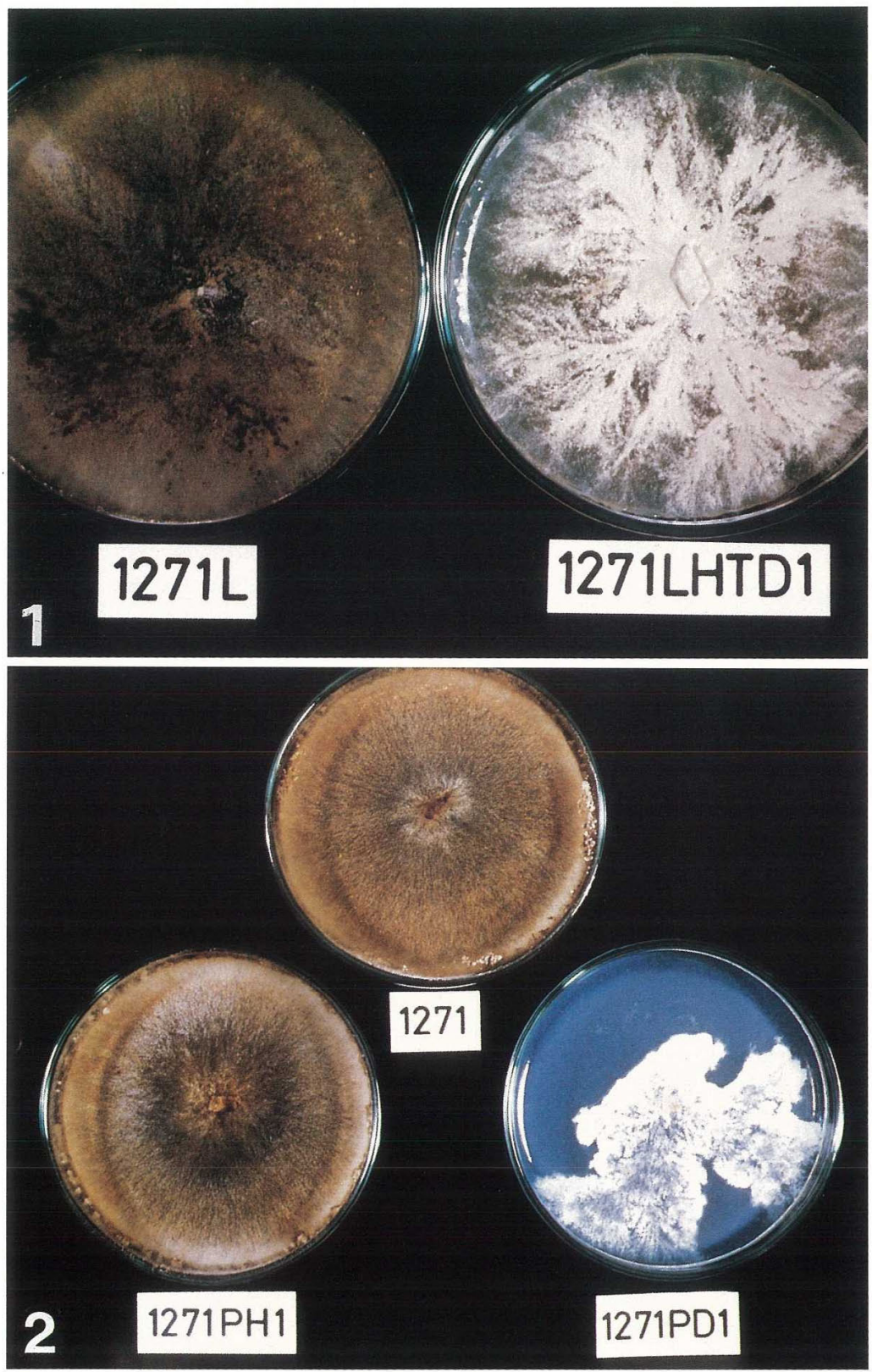

Plate I.

1. Abnormal isolate 1271LHTD1 obtained from normal isolate $1271 \mathrm{~L}$ by the hyphal tip transfer.

2. Abnormal isolate 1271PD1 and normal isolate 1271PH1 obtained from healthy isolate 1271 by the single protoplast isolation. 


\section{引 用 文 献}

1. Anagnostakis, S.L. (1982). Science 215: 466-471.

2. Banks, G.T., Buck, K.W., Chain, E.B., Himmelweit, F., Marks, J.E., Tyler, J.M., Hollings, M., Last, F.T. and Stone, O.M. (1968). Nature 218: 542-545.

3. Brasier, C.M. (1983). Ibid. 305: 220-223.

4. Castanho, B. and Butler, E.E. (1978). Phytopathology 68: 1505-1510.

5. Castanho, B. and Butler, E.E. (1978). Ibid. 68: 1511-1514.

6. Castanho, B., Butler, E.E. and Shepherd, R.J. (1978). Ibid. 68: 1515-1519.

7. Day, P.R., Dodds, J.A., Elliston, J.E., Jaynes, R.A. and Anagnostakis, S.L. (1977). Ibid. 67: 13931396.

8. Elliston, J.E. (1985). Ibid. 75: 1405-1413.

9. Esser, K. and Tudzynski, P. (1977). Nature 265: 454-456.

10. Fulbright, D.W. (1984). Phytopathology 74: 722-724.

11. Fulbright, D.W., Weidlich, W.H., Haufler, K.Z., Thomas, C.S. and Paul, C.P. (1983). Can. J. Bot. 61: 3164-3171.

12. Ghabrial, S.A., Sanderlin, R.S. and Calvert, L.A. (1979). Phytopathology 69: 312-315.

13. 羽柴輝良 (1984). 植物防疫 38: 28-33.

14. Hasiba, T., Homma, Y., Hyakumachi, M. and Matsuda, I. (1984). J. gen. Microbiol. 130: 20672070.

15. Hasiba, T. and Yamada, M. (1982). Phytopathology 72: 849-853.

16. 本間善久 - 山下洋子・久保千冬・石井正義 (1981). 日植病報 47: 388 (講要).

17. 百町満朗・本間善久 ・ 宇井格生 (1984). 同上 50: 281-285.

18. 百町満朗 - 角野晶大 - 本間善久 - 上田一郎 - 四方英四郎 (1985). 同上 $51: 372$ (講要).

19. Lindberg, G.D. (1959). Phytopathology 49: 29-32.

20. Lindberg, G.D. (1960). Ibid. 50: 457-460.

21. Lindberg, G.D. (1966), Ibid. 56: 1297-1300.

22. Lindberg, G.D. (1968). J. gen. Microbiol. 50: 361-365.

23. Sanderlin, R.S. and Ghabrial, S.A. (1978). Virology 87: 142-157.

24. 高屋茂雄 (1972). 化学々生物 10: 476-478.

25. Tudzynski, P. and Esser, K. (1977). Molec. gen. Genet. 153: 111-113.

26. Van Alfen, N.K. (1983). Ann. Rev. Phytopathol. 20: 349-362.

27. Van Alfen, N.K., Jaynes, R.A., Anagnostakis, S.L. and Day, P.R. (1975). Science 189: 890-891.

28. Wood, H.A., Bozarth, R.F. and Mislivec, P.B. (1971). Virology 44: 592-598. 